\title{
ДОСЛІДЖЕННЯ ВІДМІННОСТЕЙ ОРИГІНАЛЬНОГО ТА ДЖЕНЕРИЧНИХ ПРЕПАРАТІВ, ЩО МІСТЯТЬ БЕТАМЕТАЗОНУ ДИПРОПІОНАТ І БЕТАМЕТАЗОНУ НАТРІЮ ФОСФАТ
}

\author{
() М. Г. Левін, В. М. Брицун, О. А. Гуменюк, А. Р. Шостак, О. М. Кузнецова, \\ О. М. Терещенко, Р. А. Мелєшко, Н. В. Останіна \\ Державна установа «Інститут громадського здоров'я імені О. М. Марзєєва \\ Національної академії медичних наук України», Київ \\ britsun167@ukr.net
}

\begin{abstract}
Мета роботи. Проведення дослідження, що дасть змогу виявити різницю між оригінальним і дженеричними препаратами, лікарські форми яких мають двофразний вміст бетаметазону (бетаметазону натрію фросфат у складі водного розчину і бетаметазону дипропіонат у вигляді суспензії в цьому розчині).

Матеріали і методи. Використано оригінальний препарат бетаметазону натрію фросфату та бетаметазону дипропіонату у вигляді суспензії та його дженеричні аналоги, доступні на ринку України. Для оцінки кількості суспензії БМДП препаратів А, B, С, що перейшла у розчин 15 \% водного ізопропанолу, нами була розроблена методика з використанням приладу «Лічильник числа та розміру часток в рідких середовищах» APSS-2000.

Результати й обговорення. Здійснено візуальне вивчення механічної стабільності суспензій у запаяних ампулах, що показало різну швидкість осідання суспендованих часток у досліджуваних препаратах. Вивчено можливий вплив розчинника (розчину лідокаїну) на швидкість та ступінь осідання часток. Виявлено, що дженеричні препарати В і С суттєво відрізняються від оригінального препарату А за розподілом маси суспензії бетаметазону дипропіонату за розмірами часток. В оригінального препарату А основну масу суспензії БМдП складають частинки меншого розміру, ніж у дженериків.

Розроблено методику для визначення розчинності, за допомогою якої виявлено, що суспензія оригінального препарату А за 130 хв експозиції на орбітальному струшувачі розчиняється майже повністю (99 \%), тоді як у дженериків В і С за цей час переходить (розчиняється) у водно-ізопропанольну фазу відповідно, лише 66 і 53 \% кристалічної маси БМДП. Показано, що динаміка розчинення суспензії БМдП досліджуваних препаратів може бути відстежена з використанням приладу «Лічильник числа та розміру часток в рідких середовищах» APSS-2000. Висновки. Встановлено, що оригінальний препарат та його дженерики мають суттєві відмінності в розподілі за розмірами часток. Розроблено методику визначення розчинності оригінального препарату та дженериків. Вказана різниця стосується суспензії бетаметазону дипропіонату: дженерики відрізняються від оригінального препарату тим, що мають інший розподіл часток за розмірами, і, як наслідок, іншу поведінку в розроблених тестах на розчинність.
\end{abstract}

Ключові слова: глюкокортикоїди; бетаметазону дипропіонат; суспензія для ін'єкцій; оригінальний лікарський препарат; дженерик; оптичний мікроскоп; лічильник числа та розміру частокв відких середовищах; високоеоективна рідинна хроматографрія.

Вступ. Глюкокортикоїди - стероїдні гормони, що мають широкий спектр фрізіологічної дії і впливають на обмін речовин (контролюють кількість глюкози та глікогена), проявляють протизапальну і антистресову дії та зменшують алергічні реакції організму [3].

3 моменту відкриття і вивчення їх медико-срармакологічних властивостей цей клас сполук використовують при лікуванні ревматичних, дерматологічних, колагенових хвороб і алергічних станів. Місцеве використання глюкокортикоїдів, на відміну від перорального, внутрішньовенного і внутрішньом'язового, характеризується меншим побічним ефектом [6].
Глюкокортикоїдні препарати, як і решта лікарських засобів, можуть продукуватись в оригінальних та дженеричних формах.

Препарати-дженерики мають бути ідентичними (біоеквівалентними) оригінальним препаратам щодо вмісту активних орармацевтичних інгредієнтів, дозування, методів введення та безпеки застосування. На відміну від оригінальних ліків, дженерики, як правило, мають суттєво меншу ціну і більш доступні широкому загалу населення [2].

Одним з сучасних глюкокортикоїдних синтетичних лікарських засобів для боротьби з ревматичними,

ISSN 2312-0967. Фармацевтичний часопис. 2017. № 3 
алергічними та шкірними захворюваннями є бетаметазон, який використовується у вигляді естерів органічних та неорганічних кислот - дипропіонату (1) та фоссрату натрію (2). Бетаметазону фроссрат натрію (2) - легкорозчинний у воді компонент, що швидко всмоктується тканинами організму [4]. Бетаметазону дипропіонат (1), який практично не розчинний у воді, повільніше абсорбується - забезпечує пролонговану дію [4].<smiles>CCC(=O)OCC(=O)[C@@]1(OC(=O)CC)[C@@H](C)C[C@H]2[C@H]3CCC4=CC(=O)C=C[C@]4(C)[C@]3(F)[C@H](O)C[C@]21C</smiles>

Мета роботи - пошук суттєвих відмінностей оригінального глюкокортикоїдного препарату (А) та двох дженеричних препаратів (B, C), зареєстрованих в Україні, що містять бетаметазону дипропіонат та бетаметазону натрію фросфрат.

Розчинність лікарського препарату у водно-органічних середовищах є сурогатним маркером його біодоступності.

Ін'єкційні препарати А, В, С містять суспензію 6,43 мг бетаметазону дипропіонату (БМДП) в 1 мл розчину та 2,63 мг бетаметазону фроссрат динатрію (БМФДН) і допоміжних речовин.

Матеріали і методи. Дослідження седиментації суспензій: ампули препаратів $A, B$, С у горизонтальному положенні струшувались протягом 1 хв на збовтувачі GFL3006 (швидкість 150 циклів/хв), після чого були виставлені вертикально для спостереження процесу седиментації суспензії.

Огляд і фотографування кристалів суспензій препаратів А, В, С були здійснені з застосуванням оптичного мікроскопа «Kruss» MBL 2100.

Також проводилося порівняння швидкості седиментації суспензії у шприцах з додаванням 2 \% розчину лідокаїну.

Кількісне дослідження розподілу часток суспензій БМДП з одночасною верифрікацією отриманих результатів для доведення відсутності значущих відмінностей при різних розбавленнях було проведено 3 використанням приладу «Лічильник числа та розміру часток в рідких середовищах» (Liquid Particle Counter APSS-2000).

Вода очищена з електропровідністю 0,5 мкСм/см була отримана на приладі «Millipore Direct-Q 3 UV».

Для кожного з препаратів А, B, C переносили вміст декількох ампул даного препарату в ємність з пробкою. Перед відбором аліквоти ємність струшували до отримання однорідної суспензії, відкривали пробку та негайно відбирали аліквотну кількість розчину.

Розведення 1:100 000. Переносили мікродозатором «Eppendorf Research» 1 мкл суспензії у фрлакон 3 пробкою, що був попередньо двічі промитий вільною від механічних часток очищеною водою. Додавали 100 мл очищеної води, швидко перемішували 5 разів 3 перевертанням, приєднували орлакон до приладу APSS-2000 і здійснювали вимірювання. Після роботи<smiles>C[C@H]1C[C@H]2[C@@H]3CCC4=CC(=O)C=C[C@]4(C)[C@]3(F)[C@H](O)C[C@]2(C)[C@]1(O)C(=O)COP(=O)(O[Na])O[Na]</smiles>

прилад промивали наступною суспензією.

Подібним чином проводили вимірювання для розведень 1:50 000 (2 мкл суспензії), 1:33 000 (3 мкл суспензії), 1:25 000 (4 мкл суспензії), 1:20 000 (5 мкл суспензії), 1:10 000 (10 мкл суспензії), 1:5000 (20 мкл суспензії), 1:2 500 (40 мкл суспензії), 1:2 000 (50 мкл суспензії), 1:1 000 (100 мкл суспензії).

Після завершення роботи прилад промивали 96 \% етанолом для розчинення решти часток бетаметазону дипропіонату та очищеною водою до виконання теста придатності системи.

Для дослідження методом ВЕРХ процесу розчинення зразків препаратів А, B, C у 15 \% водному розчині ізопропанолу на орбітальному струшувачі Gerhardt RO 30 брали аліквоти (10 мкл) суспензій препаратів А, B, C, переносили до фрлаконів, що містили 25 мл 15 \% водного розчину ізопропанолу і ставили їх на струшувач. Для кожного препарату досліджувалась 6 груп по 2 фрлакони (досліди 3 двократною повторністю). Включали струшувач і через вказані в таблиці 2 проміжки часу знімали фрлакони, фрільтрували розчини через целюлозну мембрану (діаметр пор 0,45 мкм) і методом ВЕРХ визначали кількість БМдП у отриманих розчинах, що тестувалися.

Визначення методом ВЕРХ кількості бетаметазону дипропіонату здійснювали за методикою [8] на хроматографрі Agilent 1200 з спектрофотометричним детектором, методом обернено-фразової ВЕРХ в ізократичному режимі 3 детектуванням в УФ-області спектра. Тест придатності хроматографрічної системи відповідав вимогам ДФУ (для 5-ти паралельних інжекцій середнє значення коефріцієнта симетрії піків знаходилось в межах 1,05-1,12, відносне стандартне відхилення площ піків розчину порівняння менше - 2,0 \%) [1]. Використовували колонкау Hypersyl C18 (довжина 150 мм, діаметр 4,6 мм, зер-

ISSN 2312-0967. Pharmaceutical review. 2017. № 3 


\section{Analysis of drugs}

но 5 мкм), температура колонки $25^{\circ} \mathrm{C}$, швидкість рухомої фрази 1 мл/хв, $\lambda=240$ нм, об'єм інжектування 40 мкл, рухома фраза: ацетонітрил - вода (80:20). На рисунку 1 наведено хроматограму розчину препарату $\mathbf{A}$, що тестувався.

Використовували стандартні зразки USP Reference Standard бетаметазону дипропіонату виробництва фрірми Sigma-Aldrich.

Розчин порівняння для кількісного визначення: переносили 13,1 мг стандартного зразка БМдП у мірну колбу місткістю 100,0 мл, додавали 70 мл рухомої фрази, перемішували до розчинення і додавали той же розчинник до мітки. Відбирали 1,0 мл цього розчину, переносили в мірну колбу місткістю 50 мл, додавали рухому фразу до позначки і перемішували. Концентрація БМДП становила 2,62 мкг/мл.

Для оцінки кількості суспензії БМДП препаратів A, B, C, що перейшла у розчин 15 \% водного ізопропанолу, нами була розроблена методика з використанням приладу «Лічильник числа та розміру часток в рідких середовищах» APSS-2000. Було показано, что прилад «Лічильник числа і розміру часток в рідких середовищах» можна використовувати для проведення випробування розчинення для суспензій та інших продуктів, які не містять не розчинних в середовищі розчинення компонентів. У данному випадку ми використовували прилад для визначення розчинення суспензій бетаметазону дипропіонату A, B i C.

Прилад налаштовували на замкнену циркуляцію потоку, замикаючи трубкою вхід та вихід приладу. Переносили 10,0 мкл досліджуваної суспензії після струшування у фрлакон об'ємом 25 мл, додавали 25,0 мл 15\% водного ізопропанолу і включали прилад для визначення розподілу кількості частинок за розмірними сегментами. Потім перераховували ці показники в розподіл маси за розмірами (за фрормулою $\mathrm{m}=\mathrm{n} \times \mathrm{v} \times \rho$, де $\mathrm{n}-$ кількість, $\mathrm{v}-$ об'єм часток, $\rho$ - їх щільність). Всього було проведено 180 циклів (100 хвилин часу).
Результати й обговорення. Перший етап досліджень - візуальне вивчення механічної стабільності суспензій у запаяних ампулах. Ампули струшувались протягом 1 хв, після чого були встановлені вертикально для спостереження за процесом седиментації суспензії. На рисунку 2 видно, що найповільніше осаджується препарат А, найшвидше - препарат С. Різниця в швидкості осадження, зумовлена, вірогідно, різним розміром, масою і фрормою часток.

Було проведено дослідження седиментації суспензії препаратів при змішуванні з 2 \% розчином лідокаїну гідрохлориду. Результати представлені на рисунку 3.

Можна припустити, що суспензія БМдП «А» має інший розподіл часток за розмірами БМдП і/або частки суспензії БМДП «А» мають інший поліморфрізм (іншу кристалічну/аморфнну форми або їх розподіл). Тому було прийнято рішення про перехід до прямого вивчення розподілу часток у суспензіях БМдП розглянутих препаратів

Первинна оцінка відносних розмірів і форми часток була проведена методом оптичної мікроскопії. В усіх препаратах частки є скупченням (агломератами) кристалів (рис. 4). Видно, що частки суспензії оригінального препарату А мають дещо менші розміри, ніж частки дженеричних препаратів В і C.

В з'язку зі складністю використання оптичної мікроскопії для статистично значимої оцінки розподілу великого числа суспензійних часток за розмірами, нами було проведено кількісне дослідження розподілу часток БМдП з використанням приладу "Лічильник числа та розміру часток в рідких середовищах" (див. Матеріали і методи).

3 огляду на те, що дослідити частки за розмірами в суспензіях препаратів неможливо внаслідок їх високої концентрації (число часток в 1 мл повинно бути < 10 000), то виникла необхідність здійснювати вимірювання після значного розведення препаратів. Вибір розчинника для розведення був зумовлений такими параметрами, як певна в'язкість і слабка розчин-

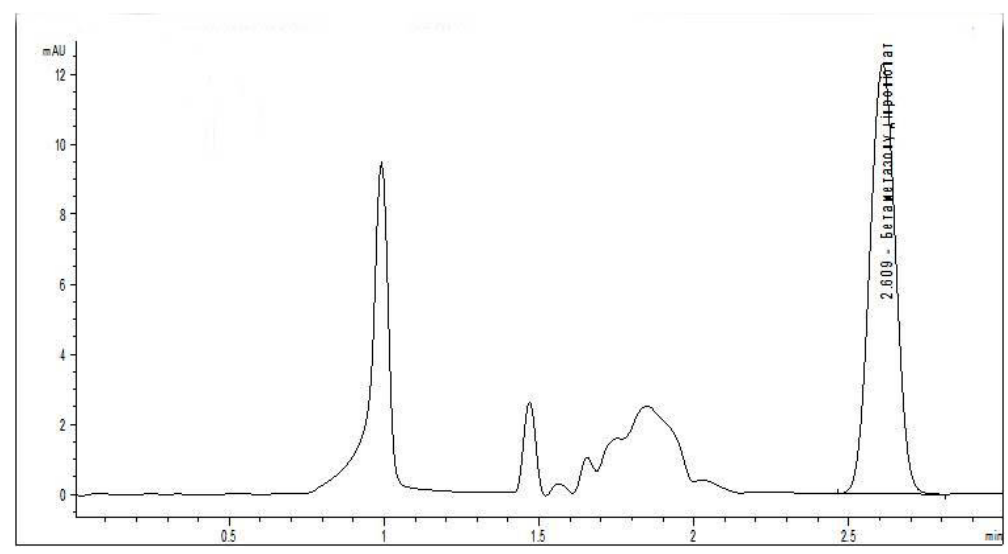

Рис. 1. Хроматограма розчину препарату А, що тестувався.

ISSN 2312-0967. Фармацевтичний часопис. 2017. № 3 


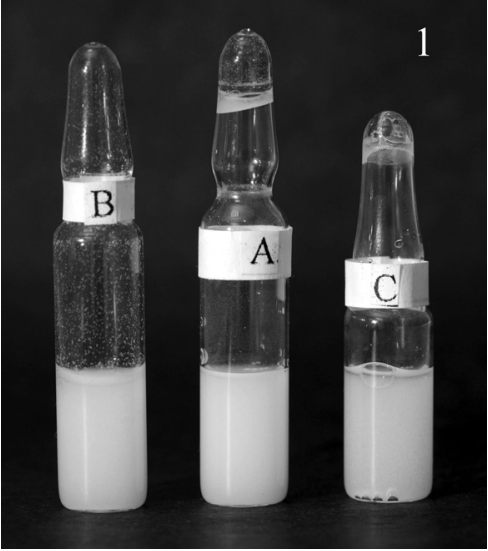

a

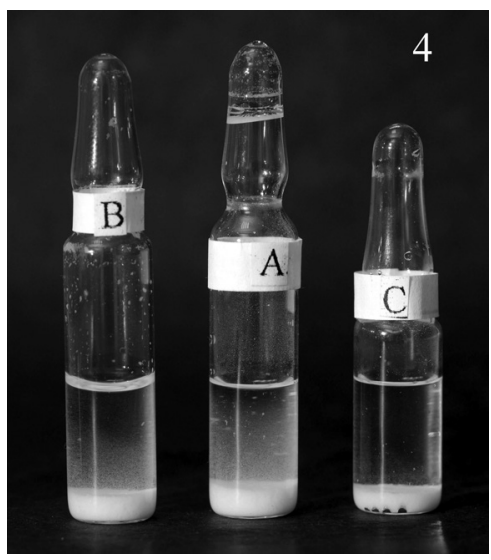

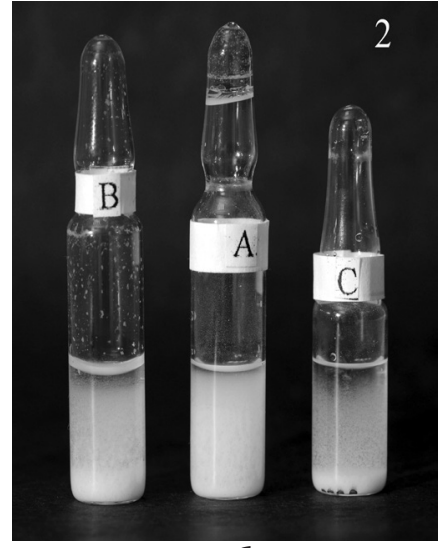

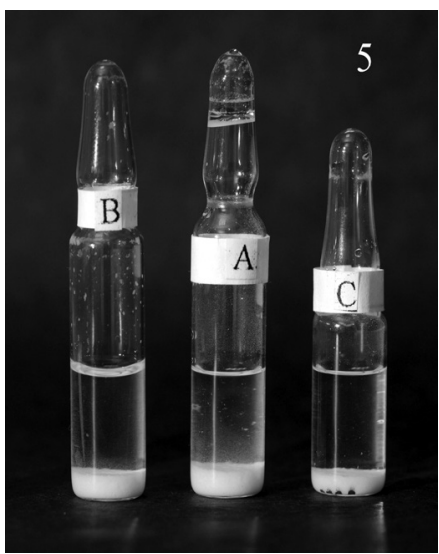

Д

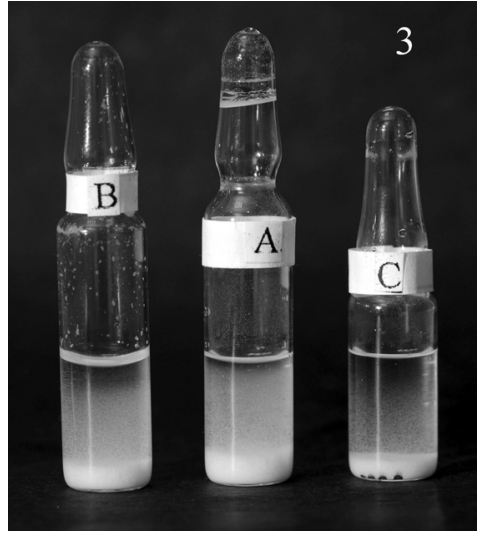

B

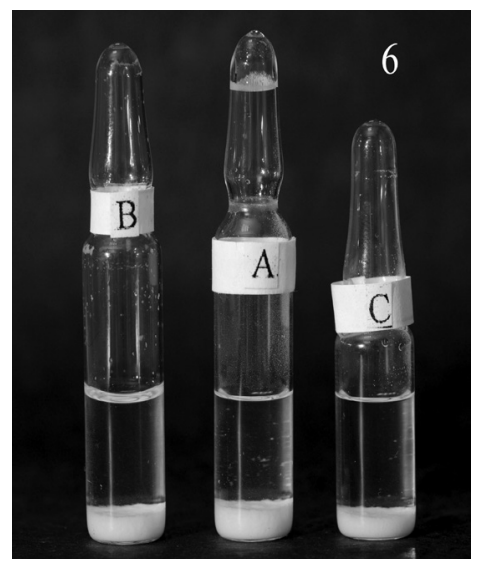

Рис. 2. Фотографрії візуального вивчення механічної стабільності суспензій у запаяних ампулах: а - старт седиментації; б - седиментація: 5 хв; в - седиментація: 10 хв; г - седиментація: 30 хв; д - седиментація: 60 хв; е - седиментація: 120 хв.

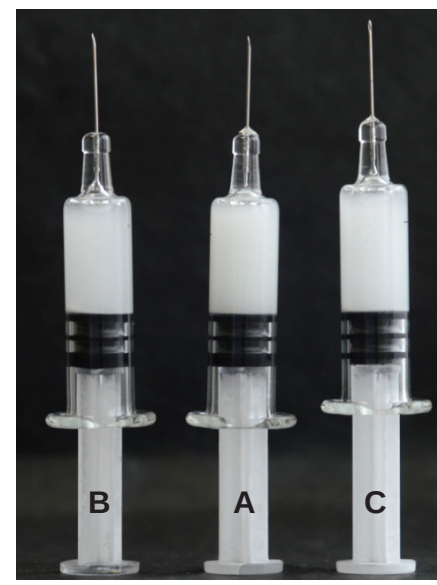

a

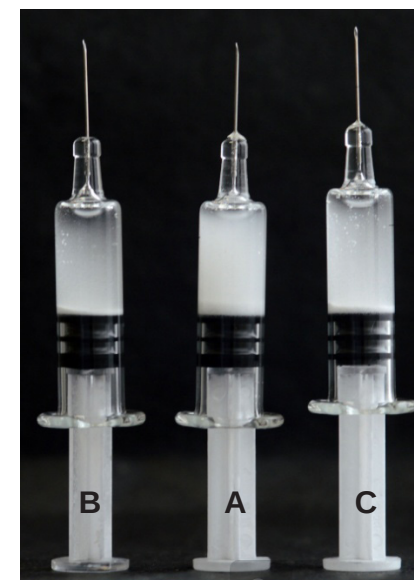

б

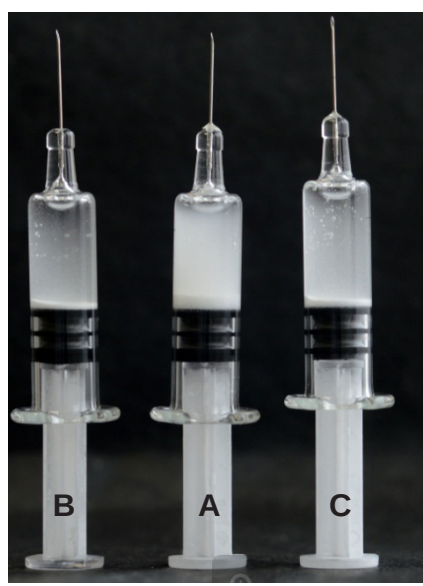

B

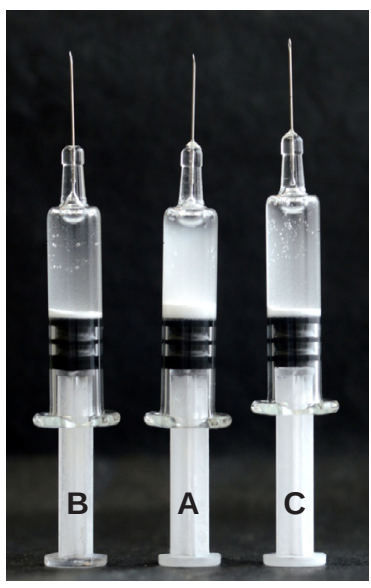

厂

Рис. 3. Фотографрії, що демонструють процес седиментації БМдП у шприцах після змішування досліджуваних препаратів з 2 мл 2 \% розчину лідокаїну: а - початок експерименту; б - те ж саме через 5 хвилин; в - те ж саме через 10 хвилин; г - те ж саме через 15 хвилин. 
Аналіз лікарських препаратів

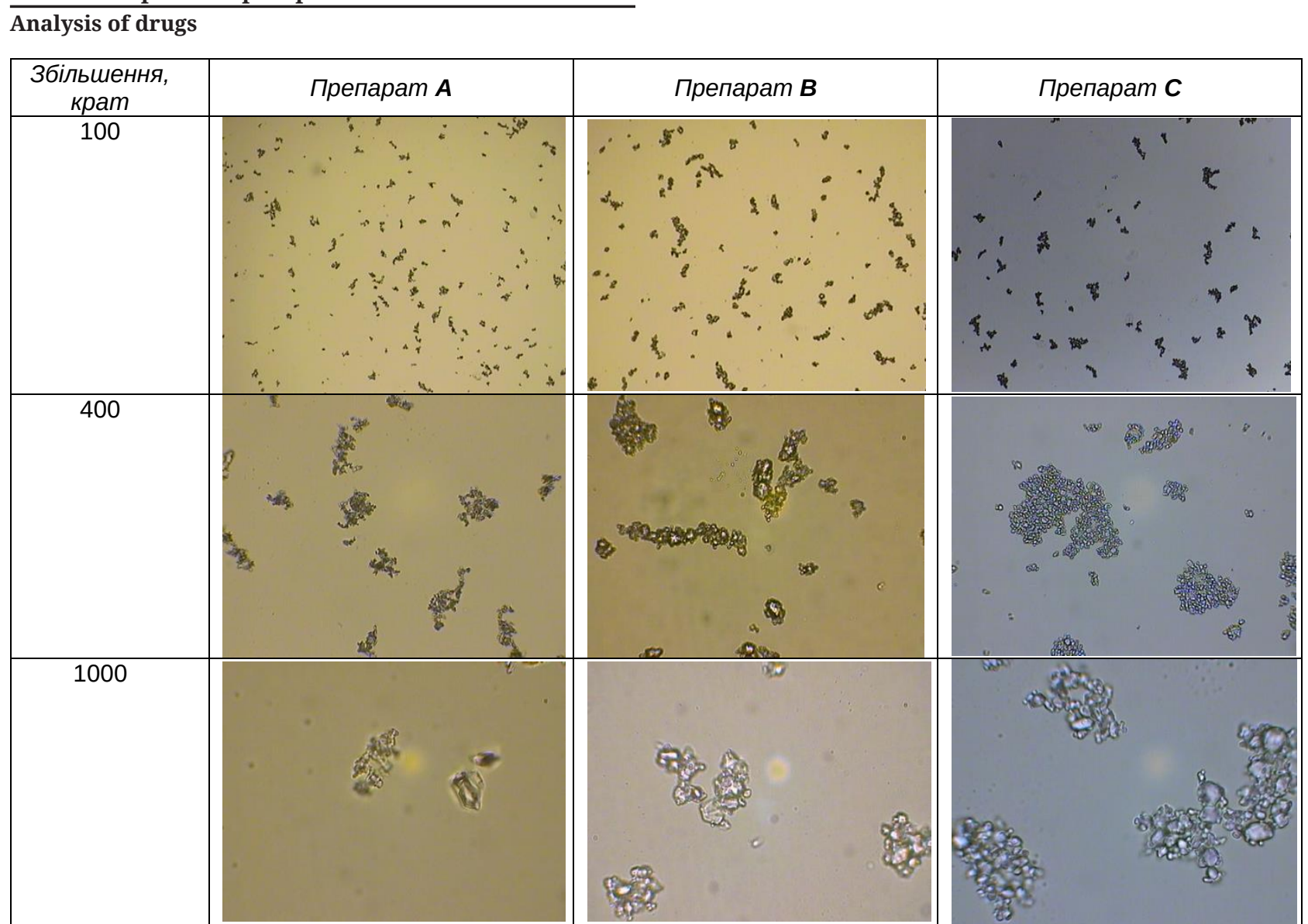

Рис. 4. Суспензії досліджуваних препаратів при збільшеннях 100x, 400x і 1000x.

ність у ньому БМДП. Цим вимогам відповідає вода, яка при $20^{\circ} \mathrm{C}$ має в'язкість $0,001 \mathrm{Па}_{*} \mathrm{C}$, і розчинність БМДП в ній при $20^{\circ} \mathrm{C}$ складає $\leq 1$ мкг/мл [7]. Тому середовищем для проведення досліджень розподілу часток за розмірами була обрана очищена вода (див. Матеріали і методи).

Попередньо були прийняті наступні допущення:

1) частки БМдП мають кубічну фрорму з розміром ребра, що знаходиться в межах розмірів даного сегмента. Для розрахунків брали максимальне значення розміру ребра для вказаного сегмента.

2) щільність часток БМДП збігається 3 густиною

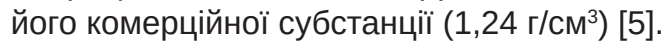

Кількість часток, що належали до кожного сегмента розмірів, вимірювали на приладі «Лічильник числа та розміру часток в рідких середовищах». Маса часток сегмента обчислювалась за фрормулою $\mathrm{m}=\mathrm{n} \times \mathrm{v} \times \rho$ (де $\mathrm{n}-$ кількість, $\mathrm{v}-$ об'єм часток, $\rho$ - їх щільність).

3 використанням цих допущень отримали дані щодо процентного розподілу маси суспензій препаратів A, B, C за розмірами часток залежно від ступеня розбавлення розчину (табл.1).

Дані таблиці 1 показують, що результати розподілу маси суспензій всіх препаратів за розмірами часток досить однорідні для 100-кратного діапазону розве- день. Для оригінального препарату А основна маса суспензії (приблизно 83 \%) складається з часток розміром 5-15 мкм. Для дженерика В приблизно 84 \% часток мають розміри 10-25 мкм, для дженерика С приблизно 81 \% суспензії - це частки розміром 10-25 мкм. Таким чином, у оригінального препарату А основну масу суспензії складають частинки меншого розміру, ніж у генериків.

На рисунку 5 представлено графік, побудований на основі усереднених даних (табл.1) залежності процентного вмісту маси суспензій БМДП препаратів A, B, C від розмірів часток.

Очевидно, що різний розмір часток суспензій досліджуваних препаратів може впливати на швидкість розчинення, тобто на біодоступність БМДП цих лікарських засобів в організмі людини.

У зв'язку в високою вартістю і складністю доклінічних випробувань in vivo на тваринах, нами було запропоновано і проведено сурогатне дослідження біодоступності БМДП вказаних лікарських засобів in vitro, яке полягало у вивченні методом BEPX процесу розчинення зразків препаратів А, В, С у 15 \% водному розчині ізопропанолу на орбітальному струшувачі (див. експериментальну частину).

Отримані результати представлені в таблиці 2 і на рисунку 6.

ISSN 2312-0967. Фармацевтичний часопис. 2017. № 3 
Таблиця 1. Розподіл маси суспензії (\%) за розмірами часток для різних розведень розчинів препаратів А, B, C

\begin{tabular}{|c|c|c|c|c|c|c|c|c|c|c|c|c|}
\hline \multirow{2}{*}{$\begin{array}{c}\text { Сегмент } \\
\text { часток, } \\
\text { мкм }\end{array}$} & \multicolumn{10}{|c|}{ Розведення, мкл суспензії препарату А на 100 мл води } & \multirow[t]{2}{*}{ середнє } & \multirow[t]{2}{*}{$\mathrm{BCB}, \%$} \\
\hline & 1 & 2 & 3 & 4 & 5 & 10 & 20 & 40 & 50 & 100 & & \\
\hline $0-2$ & 0,6 & 0,3 & 0,1 & 0,1 & 0,3 & 0,1 & 0,1 & 0,1 & 0,1 & 0,0 & 0,2 & 0,2 \\
\hline $2-5$ & 12,3 & 7,3 & 3,7 & 2,9 & 5,7 & 3,6 & 4,4 & 2,1 & 2,5 & 1,9 & 4,6 & 3,2 \\
\hline $5-10$ & 53,0 & 48,5 & 40,0 & 36,0 & 45,7 & 39,5 & 42,7 & 32,8 & 33,9 & 29,8 & 40,2 & 7,4 \\
\hline $10-15$ & 28,4 & 37,1 & 45,4 & 48,8 & 40,5 & 45,3 & 42,2 & 48,8 & 46,2 & 45,4 & 42,8 & 6,2 \\
\hline $15-25$ & 5,7 & 6,7 & 10,7 & 11,6 & 7,8 & 11,3 & 10,6 & 15,8 & 16,9 & 22,2 & 11,9 & 5,1 \\
\hline $25-50$ & 0,0 & 0,0 & 0,0 & 0,5 & 0,0 & 0,3 & 0,0 & 0,4 & 0,4 & 0,6 & 0,2 & 0,3 \\
\hline $50-75$ & 0,0 & 0,0 & 0,0 & 0,0 & 0,0 & 0,0 & 0,0 & 0,0 & 0,0 & 0,1 & 0,0 & 0,0 \\
\hline $75-100$ & 0,0 & 0,0 & 0,0 & 0,0 & 0,0 & 0,0 & 0,0 & 0,0 & 0,0 & 0,0 & 0,0 & 0,0 \\
\hline $100-125$ & 0,0 & 0,0 & 0,0 & 0,0 & 0,0 & 0,0 & 0,0 & 0,0 & 0,0 & 0,0 & 0,0 & 0,0 \\
\hline
\end{tabular}

\begin{tabular}{|c|c|c|c|c|c|c|c|c|c|c|c|c|}
\hline \multirow{2}{*}{$\begin{array}{c}\text { Сегмент } \\
\text { часток, } \\
\text { мкм }\end{array}$} & \multicolumn{10}{|c|}{ Розведення, мкл суспензії препарату В на 100 мл води } & \multirow[t]{2}{*}{ середнє } & \multirow[t]{2}{*}{$\mathrm{BCB}, \%$} \\
\hline & 1 & 2 & 3 & 4 & 5 & 10 & 20 & 40 & 50 & 100 & & \\
\hline $0-2$ & 0,2 & 0,1 & 0,1 & 0,1 & 0,1 & 0,0 & 0,0 & 0,0 & 0,0 & 0,0 & 0,1 & 0,0 \\
\hline $2-5$ & 1,7 & 1,0 & 1,2 & 1,4 & 1,2 & 0,5 & 0,5 & 0,5 & 0,3 & 0,4 & 0,9 & 0,5 \\
\hline $5-10$ & 16,2 & 14,9 & 14,5 & 15,4 & 14,4 & 8,3 & 8,4 & 7,7 & 5,8 & 7,0 & 11,3 & 4,1 \\
\hline $10-15$ & 47,4 & 39,2 & 42,0 & 43,1 & 43,9 & 38,3 & 36,7 & 36,5 & 34,6 & 35,2 & 39,7 & 4,2 \\
\hline $15-25$ & 34,6 & 38,5 & 42,3 & 39,9 & 35,1 & 49,1 & 49,6 & 51,5 & 54,6 & 52,1 & 44,7 & 7,5 \\
\hline $25-50$ & 0,0 & 6,3 & 0,0 & 0,0 & 5,3 & 3,7 & 4,8 & 3,9 & 3,9 & 5,0 & 3,3 & 2,4 \\
\hline $50-75$ & 0,0 & 0,0 & 0,0 & 0,0 & 0,0 & 0,0 & 0,0 & 0,0 & 0,8 & 0,4 & 0,1 & 0,3 \\
\hline $75-100$ & 0,0 & 0,0 & 0,0 & 0,0 & 0,0 & 0,0 & 0,0 & 0,0 & 0,0 & 0,0 & 0,0 & 0,0 \\
\hline $100-125$ & 0,0 & 0,0 & 0,0 & 0,0 & 0,0 & 0,0 & 0,0 & 0,0 & 0,0 & 0,0 & 0,0 & 0,0 \\
\hline
\end{tabular}

\begin{tabular}{|c|c|c|c|c|c|c|c|c|c|c|c|c|}
\hline \multirow{2}{*}{$\begin{array}{c}\text { Сегмент } \\
\text { часток, } \\
\text { мкм }\end{array}$} & \multicolumn{10}{|c|}{ Розведення, мкл суспензії препарату С на 100 мл води } & \multirow[t]{2}{*}{ середнє } & \multirow[t]{2}{*}{$\mathrm{BCB}, \%$} \\
\hline & 1 & 2 & 3 & 4 & 5 & 10 & 20 & 40 & 50 & 100 & & \\
\hline $0-2$ & 0,1 & 0,3 & 0,1 & 0,3 & 0,4 & 0,2 & 0,1 & 0,0 & 0,0 & 0,1 & 0,2 & 0,1 \\
\hline $2-5$ & 0,9 & 2,3 & 1,8 & 3,6 & 1,9 & 1,8 & 1,0 & 0,6 & 0,7 & 1,1 & 1,6 & 0,9 \\
\hline $5-10$ & 12,2 & 20,7 & 19,4 & 30,0 & 15,5 & 12,0 & 12,6 & 8,7 & 10,8 & 15,2 & 15,7 & 6,2 \\
\hline $10-15$ & 41,8 & 45,3 & 48,4 & 47,2 & 45,3 & 42,1 & 43,9 & 42,0 & 45,8 & 47,7 & 45,0 & 2,4 \\
\hline $15-25$ & 41,0 & 31,4 & 28,7 & 18,9 & 34,1 & 41,6 & 41,4 & 47,0 & 42,1 & 34,9 & 36,1 & 8,3 \\
\hline $25-50$ & 4,0 & 0,0 & 1,6 & 0,0 & 2,8 & 0,9 & 1,0 & 1,7 & 0,5 & 1,0 & 1,3 & 1,2 \\
\hline $50-75$ & 0,0 & 0,0 & 0,0 & 0,0 & 0,0 & 1,4 & 0,0 & 0,0 & 0,0 & 0,0 & 0,1 & 0,5 \\
\hline $75-100$ & 0,0 & 0,0 & 0,0 & 0,0 & 0,0 & 0,0 & 0,0 & 0,0 & 0,0 & 0,0 & 0,0 & 0,0 \\
\hline $100-125$ & 0,0 & 0,0 & 0,0 & 0,0 & 0,0 & 0,0 & 0,0 & 0,0 & 0,0 & 0,0 & 0,0 & 0,0 \\
\hline
\end{tabular}

Примітка. ВСВ - відносне стандартне відхилення.

Видно, що суспензія оригінального препарату А за 130 хв експозиції на орбітальному струшувачі розчиняється майже повністю (99,8 \%), тоді як у дженериків В і С за цей час переходить (розчиняється) у водно-ізопропанольну фразу відповідно, лише 66,2 та 53,3 \% кристалічної маси БМдП.

Таким чином, розроблено сурогатний тест біодоступності in vitro, який дозволяє розрізняти випробовувані препарати.
Для оцінки кількості суспензії БМДП препаратів А, B, C, що перейшла в розчин, також розроблено методику з використанням приладу «Лічильник числа та розміру часток в рідких середовищах». Результати дослідження представлені на рисунку 7.

Як видно з даних рисунка 7, крива розчинення БМДП оригінального препарату А дещо відрізняється від кривих розчинення БМДП дженериків В i C.

ISSN 2312-0967. Pharmaceutical review. 2017. № 3 
Аналіз лікарських препаратів

Analysis of drugs

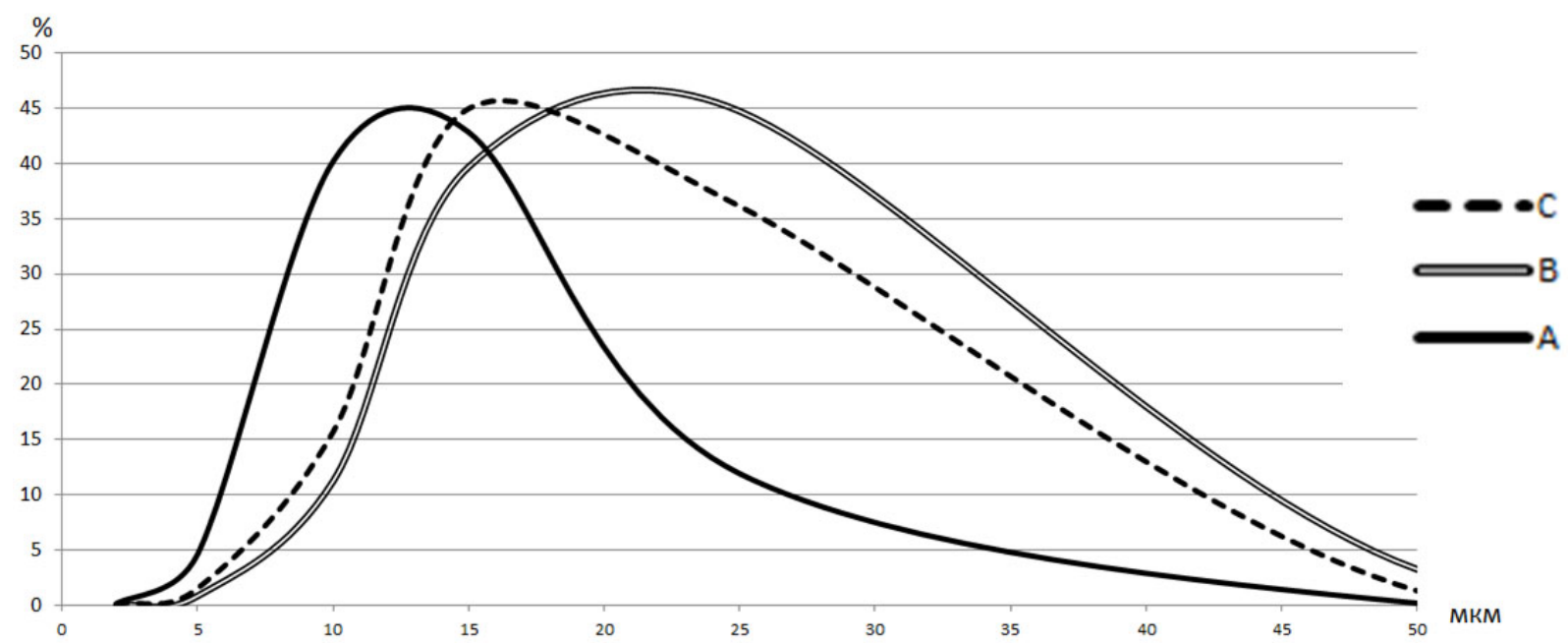

Рис. 5. Залежність кількісного вмісту маси (\%) суспензій БМдП досліджуваних препаратів від розмірів часток.

Таблиця 2. Вплив часу струшування на розчинність БМдп суспензій препаратів А, В, С у водному 15 \% ізопропанолі (за даними BEPX)

\begin{tabular}{|c|c|c|c|}
\hline \multirow{2}{*}{ Час експозиції на орбітальному струшувачі, хв } & \multicolumn{3}{|c|}{ Розчинений БМДП (\%) } \\
\cline { 2 - 4 } & $\mathbf{A}$ & $\mathbf{B}$ & $\mathbf{C}$ \\
\hline 5 & 27,2 & 24,3 & 17,4 \\
\hline 10 & 34,7 & 27,5 & 34,5 \\
\hline 20 & 67,2 & 45,3 & 44,3 \\
\hline 40 & 80,8 & 48,4 & 49,1 \\
\hline 70 & 91,0 & 57,1 & 52,4 \\
\hline 130 & 99,8 & 66,2 & 53,3 \\
\hline
\end{tabular}

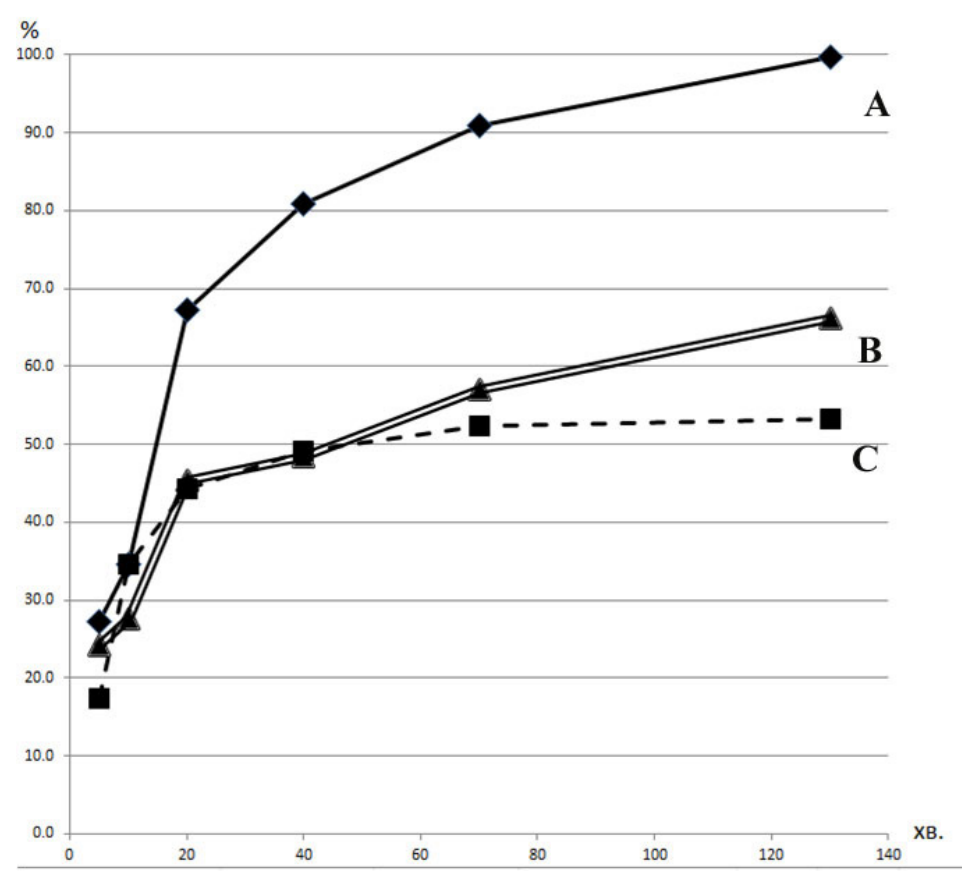

Рис. 6. Залежність розчинення (у масових \%) суспензій БМдп досліджуваних препаратів А, В, С у 15 \% водному ізопропанолі від часу експозиції на орбітальному струшувачі (за даними ВЕРX).

ISSN 2312-0967. Фармацевтичний часопис. 2017. № 3 


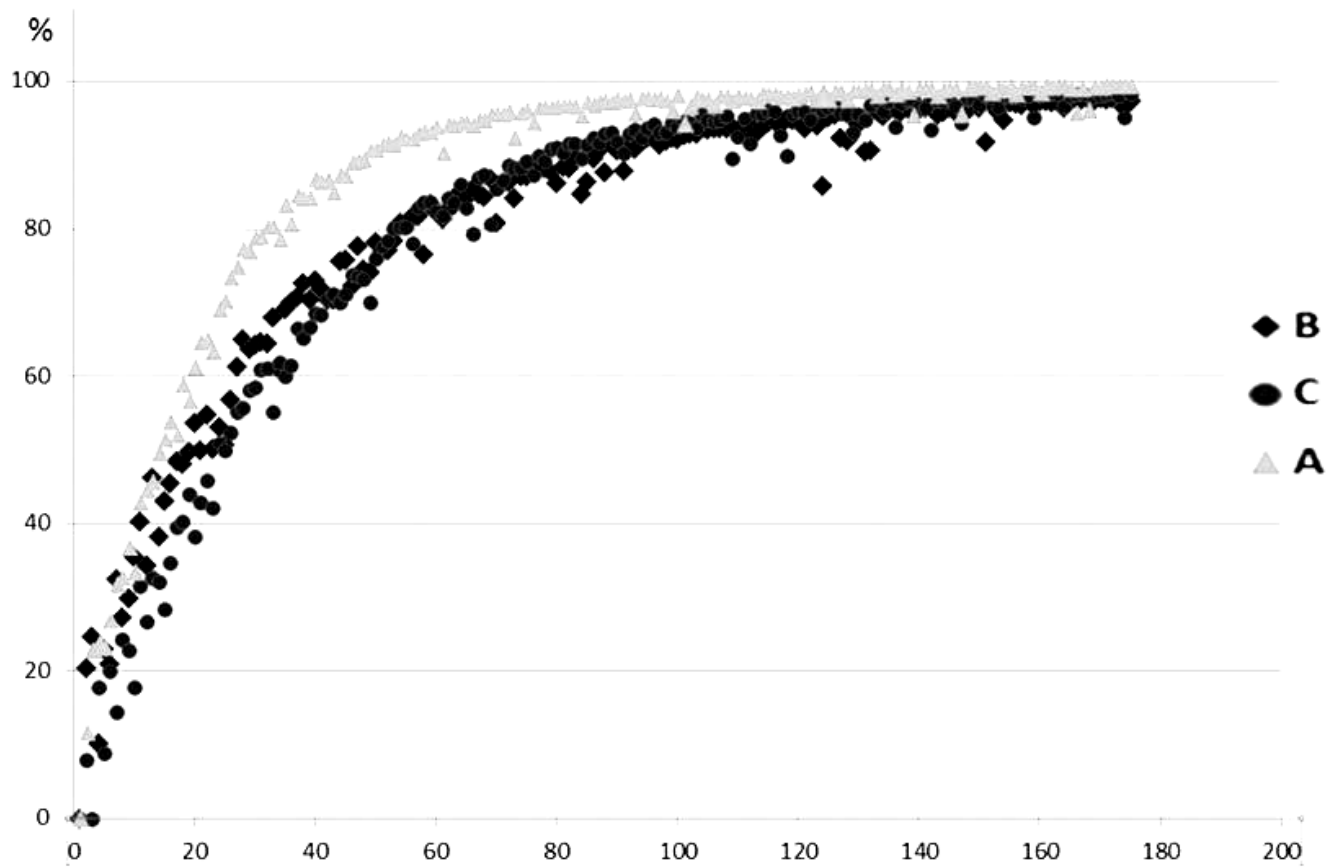

Рис. 7. Динаміка розчинення суспензії БМдп досліджуваних препаратів (масових \%) в умовах дослідження на лічильнику часток.

Висновки. Було досліджено глюкокортикоїдні препарати, що зареєстровані в Україні та містять бетаметазону дипропіонат і бетаметазону натрію фросфрат. Дженеричні препарати В і С суттєво відрізняються від оригінального препарату А за розподілом маси суспензії бетаметазону дипропіонату за розмірами часток. У оригінального препарату А основну масу суспензії БМДП складають частинки меншого розміру, ніж у дженериків. Цей фракт підтверджується такими методами, як оптична мікроскопія та визначення розподілу часток за розмірами.

Запропоновано оцінку біодоступності БМдП лікарських засобів in vitro, яка полягає в дослідженні методом BEPX розчинення зразків препаратів на орбітальному струшувачі. Виявлено, що суспензія оригінального препарату А за 130 хв експозиції на орбітальному струшувачі розчиняється майже повністю
(99 \%), тоді як у дженериків В і С за цей час переходить (розчиняється) у водно-ізопропанольну фразу відповідно, лише 66 і 53 \% кристалічної маси БМдп. Можливо, це може призводити до зменшення біодоступності БМдп in vivo, але для підтвердження цього необхідно проводити клінічні дослідження.

Також показано, що динаміка розчинення суспензії БМдП досліджуваних препаратів може бути відстежена з використанням приладу-лічильника розмірів часток.

Запропонований нами підхід є перспективним для оцінки динаміки розчинення інших лікарських засобів.

Розроблені тести дозволяють надійно відрізнити оригінальний лікарський препарат від дженериків.

Проведене дослідження свідчить про те, що за фрізико-хімічними параметрами, які можуть впливати на терапевтичну дію, препарати В і С мають суттєві відмінності від оригінального препарату А.

\title{
ИССЛЕДОВАНИЕ ОТЛИЧИЙ ОРИГИНАЛЬНОГО И ДЖЕНЕРИЧЕСКОГО ПРЕПАРАТОВ, КОТОРЫЕ СОДЕРЖАТ БЕТАМЕТАЗОНА ДИПРОПИОНАТ И БЕТАМЕТАЗОНА НАТРИЯ ФОСФАТ
}

\author{
М. Г. Левин, В.Н. Брицун, А.А. Гуменюк, А. Р. Шостак, Е. М. Кузнецова, О. Н. Терещенко, \\ Р. А. Мелешко, Н. В. Останина \\ ГУ «Институт общественного здоровья имени А. Н. Марзеева \\ Национальной академии медицинских наук Украины», Киев \\ britsun167@ukr.net
}

Цель работы. Провести исследование, которое даст возможность выявить разницу между оригинальным и дженерическими препаратами, содержащими бетаметазон (бетаметазона натрия фроссрат в виде водного раствора и бетаметазона дипропионат в виде суспензии в этом растворе).

ISSN 2312-0967. Pharmaceutical review. 2017. № 3 
Материалы и методы. Использован оригинальный препарат бетаметазона натрия фросфата и бетаметазона дипропионата в виде суспензии и его дженерические аналоги, доступные на рынке Украины. Для оценки количества суспензии БМДП препаратов А, B, С, перешедшей в раствор 15\% водного изопропанола, нами была разработана методика с использованием прибора «Счетчик числа и размера частиц в жидких средах» APSS-2000.

Результаты и обсуждения. Проводилось визуальное изучение механической стабильности суспензий в запаянных ампулах, которое показало различную скорость оседания суспендированных частиц в исследуемых препаратах. Изучалось возможное влияние растворителя лидокаина на скорость и степень оседания частиц. Выявлено, что генерические препараты В и С существенно отличаются от оригинального препарата А по распределению частиц по размерам. У оригинального препарата А основную массу суспензии БМДП составляют частицы меньшего размера, чем у генериков. Разработана методика для определения растворимости, с помощью которой показано, что суспензия оригинального препарата А за 130 мин экспозиции на орбитальном встряхивателе растворяется почти полностью (99\%, тогда как у дженериков В и С за это время переходит (растворяется) в водно-изопропанольную фразу соответственно, лишь 66 \% и 53 \% кристаллической массы БМДП. Показано, что динамика растворения суспензии БМдП исследуемых препаратов может быть отслежена с использованием прибора «Счетчик числа и размера частиц в жидких средах»APSS-2000. Выводы. Установлено, что оригинальный препарат и его дженерики имеют существенные отличия в распределении частиц по размерам. Разработана методика определения растворимости оригинального препарата и дженериков. Выявлено, что дженерики отличаются от оригинального препарата тем, что имеют другое распределение частиц по размерам.

Ключевые слова: глюкокортикоиды; бетаметазона дипропаонат; суспензия для инъекций; оригинальный лекарственный препарат; дженерик; оптический микроскоп; счетчик числа и размера частиц в жидких средах; высокоэфрфективная жидкостная хроматография.

\title{
STUDY OF DIFFERENCES OF ORIGINAL AND GENERIC PREPARATIONS WHICH CONTAIN BETAMETHASONE DIPROPIONATE AND BETAMETHASONE SODIUM PHOSPHATE
}

\author{
M. G. Levin, V. N. Britsun, A. A. Gumenyk, A. R. Shostak, O. M. Kuznetsova, O. M. Terechenko, \\ R. A. Meleeshko, N. V. Ostanina
}

State Institution «O.M. Marzeyev Institute for Public Health of the National Academy of Medical Sciences of Ukraine», Kyiv

britsun167@ukr.net

The aim of the work. The work is devoted to conduct a study that will reveal the difference between the original and generic drugs whose dosage forms have a two-phase content of betamethasone (betamethasone sodium phosphate in the aqueous solution and betamethasone dipropionate in the form of a suspension in this solution).

Materials and Methods. The original preparation of betamethasone sodium phosphate and betamethasone dipropionate in the form of a suspension and its generic analogues, adjacent to the Ukrainian market, have been used. To evaluate the amount of AMD suspension of preparations A, B, C, which was transferred to a solution of $15 \%$ aqueous isopropanol, we have developed a technique using the device "Particle number and particle counter in liquid media" APSS-2000.

Results and Discussions. A visual study of the mechanical stability of suspensions in sealed ampoules was performed, which showed a different rate of settling of suspended particles in the investigated preparations. The possible influence of lidocain solvent on the velocity and degree of settling of particles was studied. It was revealed that generic preparations $B$ and $C$ differ significantly from the original preparation $A$ in terms of particle size distribution. In the original preparation $A$, the bulk of the PMP suspension is made up of particles of smaller size than generics. The method for solubility determination has been developed by which it has been found that the slurry of the original preparation A for 130 min of exposure to the orbital shredder dissolves almost completely ( $99 \%$, while generics B and C during this time passes (dissolves) into the aqueous isopropanol phase, respectively, only $66 \%$ and $53 \%$ of the crystalline mass of the BMDP. It has been shown that the dynamics of dissolution of the PMP suspension of the investigational drugs can be traced using a "Particle number and particle counter in liquid media" APSS-2000.

Conclusions. It has been established that the original drug and its generics have significant differences in the distribution of particles in size. A method for determining the solubility of the original drug and generics has been developed. It has been shown that generics differ from the original drug by having a different particle size distribution.

Key words: glucocorticoids; betamethasone dipropionate; injectable suspension; original drug; generic; optical microscope; liquid particle counter; high performance liquid chromatography.

ISSN 2312-0967. Фармацевтичний часопис. 2017. № 3 


\section{Список літератури}

1. State Pharmacopoeia of Ukraine, T.1. - Kharkiv: "Ukrainian Scientific Pharmacopoeia Center for the Quality of Medicinal Products", 2015.

2. Baumgartel $\mathrm{C}$. Myths, questions, facts about generic drugs in the EU / C. Baumgartel // Gener. Biosim Initiate J. - 2012. Vol.1 (1). - p.34-38.

3. Coutinho A. E. The anti-inflammatory and immunosuppressive effects of glucocorticoids, recent developments and mechanistic insights / A. E. Coutinho, K. E. Chapman // Mol. Cell Endocrinol. - 2011. Vol.335 (1). - P.2-13.

4. European Pharmacopoeia, Eighth Edition, Vol.2. - Nordlingen: Druckerei C.H. Beck, 2014 - P. 1661-1663.

\section{References}

1. State Pharmacopoeia of Ukraine. [Державна фрармакопея України] Kharkov: Ukrainian Scientific Pharmacopoeia Center of Quality of Medicinal Products 2 ed. X; 2015. Ukrainian.

2. Baumgartel $\mathrm{C}$. Myths, questions, facts about generic drugs in the EU. Gener Biosim Initiate J. 2012;1(1):34-8.

3. Coutinho AE, Chapman KE. The anti-inflammatory and immunosuppressive effects of glucocorticoids, recent developments and mechanistic insights. Mol Cell Endocrinol. 2011;335(1): 2-13.

4. European Pharmacopoeia, 8th ed., Vol.2. Nordlingen: Druckerei C.H. Beck; 2014.
5. http://www.guidechem.com/dictionary/en/5593-20-4.html 6. Kadmiel M. Glucocorticoid receptor signaling in health and disease / M. Kadmiel, J. A. Cidlowski // Trends Pharm. Sci - 2013. - Vol. 34 (9). P. 518-530.

7. Simon A. Development and Validation of a discriminatory dissolution test for betamethasone sodium phosphate and betamethasone dipropionate intramuscular injectable suspension / A. Simon, V. Raphael, A. Borges, L. Cabral // AAPS Pharm. Sci. Tech. - 2013. - Vol. 14 (1) - P. 425-434. 8. The United States Pharmacopeia USP 39. NF 34, Vol.2. - Baltimore: United Book Press, 2016. - P. 2739. USP 39. NF 34, Vol.2. - Baltimore: United Book Press, 2016. - P. 2739

5. Betamethasone 17,21-dipropionate http://www. guidechem.com/dictionary/en/5593-20-4.html

6. Kadmiel M, Cidlowski JA. Glucocorticoid receptor signaling in health and disease. Trends Pharm Sci. 2013;34(9): 518-30.

7. Simon A, Raphael V, Borges A, Cabral L. Development and Validation of a Discriminatory Dissolution Test for Betamethasone Sodium Phosphate and Betamethasone Dipropionate Intramuscular Injectable Suspension. AAPS Pharm Sci Tech. 2013;14(1): 425-34.

8. The United States Pharmacopeia USP 39. NF 34, Vol.2. Baltimore: United Book Press; 2016. 2739 p. 